\title{
Natural Antioxidant and Antimicrobial and its Relation to Quality and Safety of Smoked Mullet Fish
}

\author{
'Zeitoun, R.A., ${ }^{1}$ Abdalla, A. E., ${ }^{2}$ Srour, T.M. and ${ }^{3}$ Hassanin, M.A. \\ ${ }^{1}$ Department of Food Sciences, Faculty of Agriculture, Saba Bacha \\ ${ }^{2}$ Department of Animal and Fish Production, Faculty of Agriculture, Saba Bacha \\ ${ }^{3}$ National Institute of Oceanography and Fisheries
}

\begin{abstract}
Fresh mullet (Mugil cephalus) fish of economic importance was subjected to different liquid smoked treatments; Liquid smoked (LS), LS combined with Pomegranate extract $100 \mathrm{mg} / \mathrm{kg}$ (LS+P1), LS combined with paprika powder $5 \mathrm{~g} / \mathrm{kg}$ fish (LS+P2) and $\mathrm{LS}+\mathrm{P} 1+\mathrm{P} 2$. to study the effect of these treatments on liquid smoked fish quality and safety during storage at $4{ }^{\circ} \mathrm{C}$. Results revealed that the treatment of fresh fish with $2 \%$ lactic acid buffered will exert antimicrobial, reduce $\mathrm{pH}$ and enhance safety and quality.

The mean moisture content values were $72.38 \%, 57.96 \%, 58.57 \%, 57.65 \%$ and $58.25 \%$ for fresh fish, liquid smoked (LS), LS combined with pomegranate extract $\mathrm{mg} / \mathrm{K}$ (LS+P1), LS combined with $0.5 \%$ paprika powder (LS+P2)and LS combined with pomegranate extract $100 \mathrm{mg} / \mathrm{kg}$ and $0.5 \%$ paprika powder ( $\mathrm{LS}+\mathrm{P} 1+\mathrm{P} 2)$ at respectively. All the liquid smoked process resulted in a significant decrease $(p<0.05)$ in moisture content of mullet Mugil cephalus samples as compared with fresh fish. The highest total volatile basic nitrogen (TVB-N) values were recorded in fresh fish while the lowest were shown according to the flowing order Powder (LS+P1+P2) flowed by LS combined with $100 \mathrm{mg} / \mathrm{kg} \mathrm{LS}+\mathrm{P} 1$ flowed by LS+P2 and flowed by liquid smoked (LS). Results revealed that salt content in all liquid smoked treatments were much lower than WHO recommended limit. smoked fish with low salt content will encourage consumers, improve the public health and enhance safety. The data indicate the effectiveness of pomegranate peel extract and paprika powder as natural antimicrobial and antioxidants due to the reduction in TVB-N values. Samples treated with $L S, L S+P 1, L S+P 2, L S+P 1+P 2$ have a shelf life at $4{ }^{\circ} \mathrm{C}$ of $65,70,70$ and 75 days respectively. This signifies a prolongation of shelf life at $4{ }^{\circ} \mathrm{C}$ of $59,64,64$ and 69 days, respectively as compared with untreated fish.
\end{abstract}

Key Words: Fish, Liquid smoked, quality, Pomegranate peel extract, Paprika Powder.

\section{INTRODUCTION}

Food quality and safety have become a major concern to consumers, producers, food industries, and regulatory agencies worldwide (Hassoun and Coban, 2017; Zanin et al., 2017). Fish are highly perishable food products due to microbiological activity and oxidation of lipid, which are known to be the principal causes of quality deterioration of such products(Ghaly et al., 2010; Chaillou et al., 2015; Secci and Parisi, 2016; Sun et al., 2019). Therefore, offering high quality Fish and safe combined with consumers demand for natural preservatives create challenging problems (Karoui and Hassoun, 2017; Mendonca et al., 2018). Recently, , there has been expanded focus on natural antimicrobial and antioxidant as alternatives to synthetic preservatives to enhance food safety and quality and extend the shelf life ( Çoban and Kelestemur,2016 ; Secci and Parisi , 2016; Kharchoufi et al.,2018; Mendonca et al.,2018; Pisoschi et al.,2018; Hanania et al.,2019; Ribeiro et al.,2019).

Smoking is the oldest fish preservation since it delays microbiological and oxidative changes (Goulas and Kontominas,2005; Varlet et al., 2009). Over the past three decades, liquid smoke flavours have been increasingly used as an alternative to traditional smoking (Alcicek et al.,2010; Ledesma et al.,2017; Ceylan et al.,2018) 
Liquid smoke flavours have some advantages over traditional smoking methods, such as easy application, lower cost, environmental friendliness and provides a higher diversity of smoked food and antimicrobial and antioxidant activity can be evaluated. It is also easier to control smoke contaminants like polycyclic aromatic hydrocarbons (PAHs), which are considered carcinogenic, and mutagenic molecules produced during pyrolysis of wood (Theobald et al.,2012; Mahugija and Njale,2018; Rascon et al.,2019).

Nowadays, $75 \%$ of smoked foods produced in the United States are treated with liquid smoke (Varlet et al., 2009). Fish that smoked using liquid smoking method are often done to produce a high quality smoked fish (Ledesma et al.,2017; Ceylan et al.,2018 ). Mullet (Mugil cephalus L) is one of the most widely distributed seafood fish all over the world (Waltham et al.,2013; Bouzgarrou et al.,2016; Ao et al.,2017) and play important economically and nutritionally roles in Egypt. The overall aim of the present study is to evaluate the effects of liquid smoking with pomegranate peel extract, Paprika Powder and lactic acid buffered system on the quality and safety of smoked mullet (Mugil cephalus_L) fish. Number of chemical parameters, total psychrotrophic aerobic bacteria, Enterobacteriaceae, Yeast and Moulds, and sensory analysis were measured.

\section{MATERIALS AND METHODS}

\section{Materials}

Fresh mullet fish ( Mugil cephalus $L$ ) weight $25 \mathrm{~kg}$ were purchased from the fish market ,Bahry, Alexandria and transported in ice boxes to Food science laboratory, Fac. of Agriculture, Saba Basha, Alexandria University. Sensory evaluation of raw fish freshness was carried out included Appearance, Eye, Gill, Odour, Texture and Viscera. Concentrated I.iquid smoke composition was $83 \%$ water ,6\% Acetic acid, 4\% Phenol, 3\% syringol, 2\% Guaiacol, 1\% Benzaldehyde and $1 \%$ ethan (acetaldehyde). All chemicals used were of analytical grade.

\section{Methods}

\section{Preparation of fish samples}

Fish samples were washed with tap water, removed scales, beheaded, eviscerated, cut to two pieces, washed again with tap water and allowed to drain at $4{ }^{\circ} \mathrm{C}$ for $30 \mathrm{~min}$.

\section{Preparation of pomegranate peel extract}

Pomegranate fruit having no visible external cuts or spoilage was purchased from the local market in Alexandria. The fruit was washed, and peel was separated and cut into small pieces. The pomegranate peel was dried at 50 ${ }^{\circ} \mathrm{C}$ for 4 days, powdered by grinding and sieving using a 40-mesh sieve (420 $\mu \mathrm{m})$. The extraction was obtained by mixing $20 \mathrm{gram}$ of dried pomegranate peel with $500 \mathrm{ml}$ of distilled water with shaking at $100 \mathrm{rpm}$ in dark at an ambient temperature for overnight. The obtained extracts were centrifuged at $2147 \times \mathrm{g}$ for $30 \mathrm{~min}$ followed by filtration using Whatman filter papers number 1 and concentrated in vacuum rotary evaporator. The extracts were then lyophilized to 
form powder at $-50{ }^{\circ} \mathrm{C}$ (Telstar Model 50, Spain). Pomegranate extract powder were used at $100 \mathrm{mg} / \mathrm{kg}$ fish.

\section{Preparation of Paprika}

Pepper pods of Capsicum annuum L. were purchased from local market in Alexandria. The pepper pods were washed, dried at $50{ }^{\circ} \mathrm{C}$ for 3 days, grinding and sieving using a 40-mesh sieve $(420 \mu \mathrm{m})$. Paprika Powder were used at $5 \mathrm{~g} / \mathrm{kg}$ fish.

\section{Treatment with $2 \%$ lactic acid}

Cleaned Fish were decontaminated by sprayed with $2 \%$ lactic acid. spraying was performed uniformly using a spray gun over the surface on both side of the fish. After treatment the fish were allowed to drain at $4{ }^{\circ} \mathrm{C}$ for $30 \mathrm{~min}$.

\section{Dry salting}

Decontaminated fish were dry salted at $4{ }^{\circ} \mathrm{C}$ for $24 \mathrm{~h}$ using fine refined $\mathrm{NaCl}$ (Almaks Company, Alexandria). The temperature of the dry salt was kept low $\left(4^{\circ} \mathrm{C}\right.$ ), to control microbial growth (Siskos et al., 2005; Dimitriadou et al., 2008). The ratio between salt and fish weight was 0.20 , when dry salting was completed, excess salt was removed by careful rinsing of the fish with water (approximately $20 \mathrm{sec}$ ). Before smoking, the fish were allowed to drain at $4{ }^{\circ} \mathrm{C}$ for 30min.

\section{Liquid smoking of fish samples}

The decontaminated fish were soaked for $5 \mathrm{~h}$ at $4{ }^{\circ} \mathrm{C}$ in $1000 \mathrm{ml}$ diluted liquid smoking solution (40 ml concentrated liquid smoke /L water).

Four different treatments were tested

(1) Liquid smoking and allowed to drain at $4{ }^{\circ} \mathrm{C}$ for $30 \mathrm{~min}$ (LS).

(2) Liquid smoking and treated with $100 \mathrm{mg} / \mathrm{kg}$ pomegranate peel extract allowed to drain at $4{ }^{\circ} \mathrm{C}$ for $30 \mathrm{~min}$ (LS+P1)

(3) Liquid smoking and treated with Paprika Powder $5 \mathrm{~g} / \mathrm{kg}$ (LS+P2)

(4) Liquid smoking and treated with pomegranate peel extract (LS+P1+P2) $100 \mathrm{mg} / \mathrm{kg}$ and treated with Paprika Powder $5 \mathrm{~g} / \mathrm{kg}$.

Fish Samples were dried at $70{ }^{\circ} \mathrm{C}$ for 3 hours, cooled, packed separately in polyethylene bags and stored at $4{ }^{\circ} \mathrm{C}$ for 75 days. Samples were analyzed chemical, Microbiological and Sensory after 0, 6, 15, 30, 45, 60,65, 70 and 75 days of storage.

\section{Chemical analysis \\ Proximate composition analyses}

Moisture, Protein, fat and ash of the fish samples were determined according to the standard methods of AOAC (1984).

\section{Determination of $\mathrm{pH}$}

The $\mathrm{pH}$ value was determined according to the method of Wang et al. (2014). Ten gram of fish sample was homogenized with $90 \mathrm{ml}$ distilled water in a blender for $1 \mathrm{~min}$. The $\mathrm{pH}$ value was measured using a $\mathrm{pH}$ meter (Mettler Toledo Co., Zurich, Switzerland) at ambient temperature. 


\section{Determination of salt}

The Salt percentage was determined according to the procedure of Pearson (1973). One gram of fish fillet homogenate was mixed with $50 \mathrm{ml}$ of distilled water and titrated with $0.1 \mathrm{~N}$ silver nitrate using $0.5 \mathrm{ml}$ of $5 \%$ potassium chromate to the first appearance of a slight orange color against the yellow color of the indicator. The $\mathrm{NaCl}$ percentage in fish samples were calculated as $1 \mathrm{ml}$ of $0.1 \mathrm{AgNO} 3=0.005845 \mathrm{~g}$ of $\mathrm{NaCl}$.

\section{Determination of total volatile basic nitrogen (TVB-N)}

The determination of TVBN was conducted according to the procedure of Miller (1998). $10 \mathrm{~g}$ of sample was blended with $50 \mathrm{ml}$ of distilled water; the blender was washed with $250 \mathrm{ml}$ of distilled water into the distillation flask and 1 $\mathrm{g}$ of magnesium oxide was added to the mixture. The TVB-N was released by boiling the mixture with magnesium oxide, which prevented volatile acids from distilling over into the boric acid. The distillate of volatile nitrogen was received in $25 \mathrm{ml}$ of boric acid $2.0 \%$ then titrated by $0.1 \mathrm{~N}$ sulfuric acid and methyl red was used as indicator.

TVB-N (mg N/100 $\mathrm{g}$ of fish) = Titration $(\mathrm{ml}$ of $0.1 \mathrm{~N}$ sulfuric acid $) \times 14$.

\section{Microbiological analyses}

Three samples of $10 \mathrm{~g}$ fish were sampled aseptically and homogenized with $100 \mathrm{ml}$ sterile saline solution $(0.85 \% \mathrm{NaCl}$, w/v) for $2 \mathrm{~min}$. From this homogenate decimal dilutions were made in sterile physiological saline containing $0.1 \%$ peptone. Psychrotrophic aerobic bacteria colony forming units were determined in plate count agar (PCA) (Oxoid CM 325), incubated for up to 5 days at $20{ }^{\circ} \mathrm{C}$. Yeast and mould colony forming units were determined on Rose Bengal Chloramphenicol agar (Oxoid CM 549) with supplement (chloramphenicol antibiotic supplement (Oxoid SR 78), incubated up to 5 days at $30{ }^{\circ} \mathrm{C}$. Enterobacteriaceae were determined as colony forming units on violet Red Bile Glucose agar (VRBG) (Oxoid CM 485) with an overlay of the same agar incubated for $18 \mathrm{~h}$ at $37^{\circ} \mathrm{C}$ (Zeitoun et al.,1994).

The microbial population of each plate was counted and reported as $\log _{10}$ CFU/g.

\section{Statistical analyses}

All experiments were carried out in triplicate and average values with standard errors were reported. Analysis of variance (ANOVA) was conducted and differences between variables were tested for significance by one-way ANOVA with Tukey's post test using graphpad instat version 3.05 for Windows 95 (GraphPad Software, San Diego CA, USA). A statistical difference at $P<$ 0.05 was considered to be significant.

\section{RESULTS AND DISCUSSION}

Freshness is a major contribution to quality of fish and fishery products. For all kinds of products, freshness is essential for the quality of the final product. A series of changes take place in fish immediately under ispostharvest condition (Olafsdottir et al. 1997; Diop,,et al.,2016.; Lazo et al.,2017 )Therefore, sensory evaluation assessment of raw fish quality is the primary way to evaluate freshness. Appearance, eye, gill, odour, texture and viscera of fresh Mullet (Mugil cephallus) fish were examined by five panelists with 9 for highest score(Table 1). 
Table (1). Sensory evaluation of Raw Mullet (Mugil cephallus) fish

\begin{tabular}{cccccc}
\hline Appearance & Gill & Eye & Odor & Texture & Viscera \\
\hline 8.45 & 8.72 & 8.50 & 8.11 & 8.26 & 8.41 \\
$( \pm 0.14)$ & $( \pm 0.12)$ & $( \pm 0.18)$ & $( \pm 0.23)$ & $( \pm 0.13)$ & $( \pm 0.15)$ \\
\hline
\end{tabular}

The values stated refer to three samples, with SD in brackets.

The results presented in Table (1) showed the initial values for appearance, Gill, Eye, odor, texture and viscera, were 8.45, 8.72, 8.50, 8.11, 8.26 and 8.41 at respectively. The fresh Mullet fish exhibited high sensory quality. Lactic acid is the most widely utilized organic acid in the food pharmaceutical, cosmetics and chemical industries. Its production is currently attracting a great deal of research and development (Wang et al.,2013; Noori et al., 2018) and it has been generally recognized as safe (GRAS) by the U.S. Food and Drug Administration (Wang et al.,2013). The effect of the treatment with lactic acid buffered system on $\mathrm{pH}$ and microbiological quality of fresh fish is shown in Table (2), the results revealed the decontaminating effect of lactic acid. The use of $2 \%$ lactic acid buffered system resulted in a reduction of 1.77 and 0.54 log CFU/g for psychrotrophic aerobic bacteria and yeast respectively as compared with blank samples. He assessment of Enterobacteriaceae commonly forms part of the microbiological quality monitoring of foods safety ( Zeitoun et al.,1994). A reduction of Enterobacteriaceae CFU/g from $\log _{10}=3.16$ to $\log _{10}=1.62$ was obtained. Likewise, a reduction of $1.12 \mathrm{pH}$ units is obtained by treatment with $2 \%$ lactic acid. According to Shirazinejad et al., (2010) and Metin et al., (2001), the treatment with 1-3\% lactic acid resulted antimicrobial effect without adverse effects on sensory properties in seafood. The treatment of fish with $2 \%$ lactic acid buffered will exert antimicrobial, reduce $\mathrm{pH}$ and enhance safety and quality.

Table (2). Effect of the treatment with $2 \%$ lactic acid buffered system on the microbiological quality of fresh fish

\begin{tabular}{ccccc}
\hline \multirow{2}{*}{ Treatment } & $\mathbf{p H}$ & \multicolumn{3}{c}{ Log CFU/g } \\
\cline { 3 - 5 } & & $\begin{array}{c}\text { Psychrotrophic } \\
\text { aerobic bacteria }\end{array}$ & Enterobacteriaceae & Yeast \\
\hline Fresh Fish & $6.42^{\mathrm{a}}$ & $4.62^{\mathrm{a}}$ & $3.16^{\mathrm{a}}$ & $2.64^{\mathrm{a}}$ \\
& $(0.053)$ & $(0.108)$ & $(0.210)$ & $(0.140)$ \\
\hline Treated with 2\% lactic & $5.30^{\mathrm{b}}$ & $2.85^{\mathrm{b}}$ & $1.62^{\mathrm{b}}$ & $2.10^{\mathrm{b}}$ \\
acid buffered system $\mathrm{pH} 3$ & $(0.044)$ & $(0.144)$ & $(0.103)$ & $(0.100)$
\end{tabular}

Values in the same column with the same superscripts are not significantly different $(P \geq 0.05)$

The values stated refer to three samples with SD in brackets.

The approximate composition of fresh and liquid smoked fish treated with pomegranate peel extract and paprika powder was evaluated as shown in Table (3). 
Table (3). Chemical composition percentage of fresh and liquid smoked mullet Mugil cephalus fish treated with pomegranate peel extract and paprika powder

\begin{tabular}{ccccc}
\hline Treatment & $\begin{array}{c}\text { Moisture } \\
\text { Percent }\end{array}$ & $\begin{array}{c}\text { Protein } \\
\text { Percent }\end{array}$ & $\begin{array}{c}\text { Fat } \\
\text { Percent }\end{array}$ & $\begin{array}{c}\text { Ash } \\
\text { Percent }\end{array}$ \\
\hline Fresh fish & $72.38^{\mathrm{a}}( \pm 0.82)$ & $17.19^{\mathrm{b}}( \pm 0.71)$ & $5.84^{\mathrm{c}}( \pm 0.55)$ & $4.59^{\mathrm{c}}( \pm 0.28)$
\end{tabular}

\begin{tabular}{|c|c|c|c|c|}
\hline Liquid smoked (LS) & $57.96^{\mathrm{b}}( \pm 0.36)$ & $27.20^{a}( \pm 0.52)$ & $8.89^{\mathrm{a}}( \pm 041)$ & $5.95^{\mathrm{b}}( \pm 0.17)$ \\
\hline $\begin{array}{l}\text { Liquid smoked combined with } \\
\text { pomegranate extract } \\
100 \mathrm{mg} / \mathrm{kg}(\mathrm{LS}+\mathrm{P} 1)\end{array}$ & $58.57^{\mathrm{C}}( \pm 0.42)$ & $27.31^{\mathrm{a}}( \pm 0.40)$ & $8.40^{b}( \pm 0.38)$ & $5.72^{\mathrm{b}}( \pm 0.19)$ \\
\hline $\begin{array}{l}\text { Liquid smoked combined with } \\
0.5 \% \text { Paprika Powder (LS+P2) }\end{array}$ & $57.65^{\mathrm{b}}( \pm 0.35)$ & $27.51^{\mathrm{a}}( \pm 0.47)$ & $8.58^{\mathrm{b}}( \pm 0.35)$ & $6.26^{a}( \pm 0.21)$ \\
\hline $\begin{array}{c}\text { Liquid smoked combined with } \\
\text { pomegranate extract } 100 \mathrm{mg} / \mathrm{kg} \\
\text { and } 0.5 \% \text { Paprika Powder } \\
\text { (LS+P1+P2) }\end{array}$ & $58.25^{\mathrm{c}}( \pm 0.37)$ & $27.47^{\mathrm{a}}( \pm 0.59)$ & $8.38^{\mathrm{b}}( \pm 0.37)$ & $5.90^{\mathrm{b}}( \pm 0.23)$ \\
\hline
\end{tabular}

Values in the same column with the same superscripts are not significantly different $(P \geq 0.05)$.

The values stated refer to three samples, with \pm SD.

The data revealed the moisture, protein, lipid and ash content of raw and liquid-smoked mullet (Mugil cephalus) fish. The mean moisture content values were $72.38 \%, 57.96 \%, 58.57 \%, 57.65 \%$ and $58.25 \%$ for fresh fish, liquid smoked (LS), LS combined with pomegranate extract $100 \mathrm{mg} / \mathrm{kg}$ (LS+P1), LS combined with $0.5 \%$ paprika powder (LS+P2)and LS combined with pomegranate extract $100 \mathrm{mg} / \mathrm{kg}$ and $0.5 \%$ paprika powder (LS+P1+P2), respectively. All the liquid smoked process resulted in a significant decrease ( $p$ $<0.05$ ) in moisture content of mullet Mugil cephalus samples as compared with fresh fish. This decrease in moisture content values might be due to salting and drying during smoking (Cardinal et al., 2001; Alcicek,2011). Industrial specifications for "smoked finished products" generally recommend a water content in the fish flesh of less than 65\% (Kharchoufi et al., 1998; Cardinal et al., 2001; Alcicek,2011). These values are higher than our values for all liquid smoked treatments.

The percentages of total lipid, protein, and ash, of liquid-smoked mullet (Mugil cephalus) fish were significantly increased $(p<0.05)$ due to moisture loss during processing similar findings were reported by other researchers (Goulas and Kontominas,2005; Alcicek,2011; Al-Reza.,2015). The fat content of LS+P1, LS+P2 and LS+P1+P2 samples were significantly decreased $(p<$ $0.05)$ compared with LS. Protein content of LS+P1 (27.31), LS+P2 (27.51) and LS+P1+P2 (27.47) were slightly increased compared with LS. These results are in agreement with those obtained by Alcicek (2011) and Iheagwara (2013) who found treatment with thyme oil or ginger extract combined with liquid smoked caused an increase of protein and decrease of fat contents. Ash contents increased significantly $(p<0.05)$ in all liquid smoked treatment compared with fresh fish. Chemical quality changes of Liquid smoked mullet (Mugil cephalus) fish during storage at $4{ }^{\circ} \mathrm{C}$ are given in Tables (4). 
Table (4). Chemical quality changes of Liquid smoked mullet (Mugil cephalus) fish during storage at $4{ }^{\circ} \mathrm{C}$.

\begin{tabular}{|c|c|c|c|c|c|c|c|c|c|c|}
\hline \multirow{2}{*}{ Parameters } & \multirow{2}{*}{ Fish group } & \multicolumn{9}{|c|}{ Days of storage at $4{ }^{\circ} \mathrm{C}$} \\
\hline & & 0 & 6 & 15 & 30 & 45 & 60 & 65 & 70 & 75 \\
\hline TVB-N mg N/100 g of fish & $\begin{array}{c}\text { Fresh fish } \\
\text { LS } \\
\text { LS+P1 } \\
\text { LS+P2 } \\
\text { LS+P1+P }\end{array}$ & $\begin{array}{l}10.28^{\mathrm{a}} \\
8.35^{\mathrm{b}} \\
7.02^{\mathrm{d}} \\
7.57^{\mathrm{c}} \\
6.65^{\mathrm{e}}\end{array}$ & $\begin{array}{l}29.18^{a} \\
9.82^{b} \\
7.86^{c} \\
8.02^{c} \\
7.11^{d}\end{array}$ & $\begin{array}{c}\text { n.d. } \\
11.94^{a} \\
9.08^{b} \\
9.24^{b} \\
8.17^{c}\end{array}$ & $\begin{array}{c}\text { n.d. } \\
16.82^{a} \\
12.08^{b} \\
12.25^{b} \\
10.02^{c}\end{array}$ & $\begin{array}{c}\text { n.d. } \\
20.75^{a} \\
16.04^{b} \\
15.85^{b} \\
13.56^{c}\end{array}$ & $\begin{array}{c}\text { n.d. } \\
25.18^{a} \\
22.85^{b} \\
22.72^{b} \\
18.12^{\mathrm{c}}\end{array}$ & $\begin{array}{c}\text { n.d. } \\
28.96^{a} \\
24.77^{b} \\
24.89^{b} \\
20.15^{c}\end{array}$ & $\begin{array}{c}\text { n.d. } \\
\text { n.d. } \\
28.85^{a} \\
28.94^{a} \\
23.87^{b}\end{array}$ & $\begin{array}{c}\text { n.d. } \\
\text { n.d. } \\
\text { n.d. } \\
\text { n.d. } \\
28.75^{a}\end{array}$ \\
\hline Salt content $\mathrm{g} / 100 \mathrm{~g}$ fish & $\begin{array}{c}\text { Fresh fish } \\
\text { LS } \\
\text { LS+P1 } \\
\text { LS+P2 } \\
\text { LS+P1+P }\end{array}$ & $\begin{array}{l}0.18^{\mathrm{b}} \\
1.79^{\mathrm{a}} \\
1.66^{\mathrm{a}} \\
1.77^{\mathrm{a}} \\
1.74^{\mathrm{a}}\end{array}$ & $\begin{array}{l}0.20^{\mathrm{b}} \\
1.77^{\mathrm{a}} \\
1.68^{\mathrm{a}} \\
1.78^{\mathrm{a}} \\
1.74^{\mathrm{a}}\end{array}$ & $\begin{array}{l}\text { n.d. } \\
1.78^{a} \\
1.74^{a} \\
1.75^{a} \\
1.75^{a}\end{array}$ & $\begin{array}{l}\text { n.d. } \\
1.84^{\mathrm{a}} \\
1.75 \\
1.74^{\mathrm{a}} \\
1.75^{\mathrm{a}}\end{array}$ & $\begin{array}{c}\text { n.d. } \\
1.88^{a} \\
1.77^{a} \\
1.76^{a} \\
1.76^{a}\end{array}$ & $\begin{array}{l}\text { n.d. } \\
1.94^{\mathrm{a}} \\
1.79^{\mathrm{a}} \\
1.78^{\mathrm{a}} \\
1.79^{\mathrm{a}}\end{array}$ & $\begin{array}{l}\text { n.d. } \\
1.98^{\mathrm{a}} \\
1.82^{\mathrm{a}} \\
1.83^{\mathrm{a}} \\
1.80^{\mathrm{a}}\end{array}$ & $\begin{array}{l}\text { n.d. } \\
\text { n.d. } \\
1.84^{a} \\
1.83^{a} \\
1.81^{a}\end{array}$ & $\begin{array}{l}\text { n.d. } \\
\text { n.d. } \\
\text { n.d. } \\
\text { n.d. } \\
1.82^{\text {a }}\end{array}$ \\
\hline $\mathrm{pH}$ & $\begin{array}{c}\text { Fresh fish } \\
\text { LS } \\
\text { LS+P1 } \\
\text { LS+P2 } \\
\text { LS+P1+P }\end{array}$ & $\begin{array}{l}6.56^{\mathrm{a}} \\
5.28^{\mathrm{b}} \\
5.30^{\mathrm{b}} \\
5.32^{\mathrm{b}} \\
5.29^{\mathrm{b}}\end{array}$ & $\begin{array}{l}6.96^{\mathrm{a}} \\
5.32^{\mathrm{b}} \\
5.38^{\mathrm{b}} \\
5.45^{\mathrm{b}} \\
5.28^{\mathrm{b}}\end{array}$ & $\begin{array}{c}\text { n.d. } \\
5.58^{a} \\
5.53^{a} \\
5.49^{a} \\
5.37^{a}\end{array}$ & $\begin{array}{c}\text { n.d. } \\
5.77^{\mathrm{a}} \\
5.67^{\mathrm{a}} \\
5.53^{\mathrm{ab}} \\
5.42^{\mathrm{b}}\end{array}$ & $\begin{array}{c}\text { n.d. } \\
6.08^{\mathrm{a}} \\
5.77^{\mathrm{b}} \\
5.73^{\mathrm{b}} \\
5.45^{\mathrm{c}}\end{array}$ & $\begin{array}{l}\text { n.d. } \\
6.42^{\mathrm{a}} \\
6.07^{\mathrm{b}} \\
6.01^{\mathrm{b}} \\
5.65^{\mathrm{c}} \\
\end{array}$ & $\begin{array}{l}\text { n.d. } \\
6.76^{\mathrm{a}} \\
6.44^{\mathrm{b}} \\
6.38^{\mathrm{b}} \\
6.02^{\mathrm{c}} \\
\end{array}$ & $\begin{array}{l}\text { n.d. } \\
\text { n.d. } \\
6.78^{a} \\
6.72^{a} \\
6.34^{b}\end{array}$ & $\begin{array}{l}\text { n.d. } \\
\text { n.d. } \\
\text { n.d. } \\
\text { n.d. } \\
6.75^{\text {a }}\end{array}$ \\
\hline
\end{tabular}

Values in the same column with the same superscripts are not significantly different $(P \geq 0.05)$.

The values stated refer to three samples.

n.d.= not determined because of spoilage. 
The total volatile basic nitrogen (TVB-N) present in the flesh of fish is recognized as indicator of freshness by A European Union (Wells et al.,2019). The total volatile basic nitrogen consisting of volatile amines, such as ammonia (NH3), dimethyl amine (DMA) and trimethyl amine (TMA), that are responsible for the fishy odor associated with fish spoilage (Pezeshk et al,2011; Sampels, 2015; Wells et al.,2019).

The analysis of total volatile basic nitrogen (TVB-N) is widely used to determine the quality and shelf life of fish; its increase is related to the activity of microbial spoilage and endogenous enzymes (Guan et al.,2019; Wells et al.,2019). The initial level of TVB-N concentration in fresh marine $M$. cephalus muscle samples (control) was $10.28 \mathrm{mg} \mathrm{N} / 100 \mathrm{~g}$, is indicative of freshness of the raw fish, the value is in agreement with values reported in other studies for marine M. cephalus (Jnr et al., 2006; Orak, and Kayisoglu,2008; Mostafa and Salem, 2015).

The highest TVB-N values were recorded in fresh fish while the lowest were shown according to the flowing order liquid smoked combined with 100 $\mathrm{mg} / \mathrm{kg}$ and $0.5 \%$ Paprika Powder (LS+P1+P2) flowed by LS combined with 100 $\mathrm{mg} / \mathrm{kg}$ (LS+P1) flowed by LS treated with 0.5\% Paprika Powder(LS+P1) and flowed by liquid smoked (LS). The TVB-N for fresh samples (untreated) increased rapidly and rich to $29.10 \mathrm{mg} \mathrm{N} / 100 \mathrm{~g}$ after 6 days of storage at $4{ }^{\circ} \mathrm{C}$.

The increase in the TVB-N value is mainly due to the activity of endogenous enzymes and the degrading bacteria (Ozogul et al., 2004). Significant decrease of TVB-N values $(P<0.05)$ were found after liquid smoked fish treatments comparing to the fresh fish. possibly due to a treatment with lactic acid, salting; the antimicrobial and the antioxidant activity of liquid smoked, pomegranate peel extract and paprika Powder. and finally, due to drying at $70{ }^{\circ} \mathrm{C}$ for 3 hours. Previous study showed that liquid smoking reduces the accumulation of TVB-N in the muscle (Goulas and Kontominas 2005; Alcicek, 2014; Lingbeck et al.,2014; Bouzgarrou et al.,2016).

According to Alcicek (2011) the limits of safety consumption fisheries products namely by TVBN value $30 \mathrm{mg}$ while a level of $35-40 \mathrm{mg}$ TVB-N/100 $\mathrm{g}$ of fish muscle is generally identified as the fishy food decomposition (Fan \& Zhang, 2008; Ghaly et al.,2010).

Interestingly, the detected TVB-N values in this work were obviously lower than the criterion of decomposition and criterion of spoilage in all liquid smoked samples during 65 days of storage at $4{ }^{\circ} \mathrm{C}$.

According to highest acceptable TVB-N value of $30 \mathrm{mg} / 100 \mathrm{~g}$, all samples at the end of storage periods were below the critical marginal quality, followed by off odour next day. According to that limit, samples treated with LS, $\mathrm{LS}+\mathrm{P} 1, \mathrm{LS}+\mathrm{P} 2$, LS+P1+P2 have a shelf life at $4{ }^{\circ} \mathrm{C}$ of 65,$70 ; 70$ and 75 days respectively. This signifies a prolongation of shelf life at $4{ }^{\circ} \mathrm{C}$ of $59,64,64$ and 69 days respectively as compared with untreated fish. This could be explained by synergistic effect between LS and P1, LS and P2, LS and P1+P2. In this study during storage period at $4{ }^{\circ} \mathrm{C}$ TVB-N values were affected significantly $(P<$ 
0.05 ) by the treatment with Liquid smoke, pomegranate peel extract, paprika powder and the storage time. The results revealed the effectiveness of pomegranate peel extract and paprika powder as natural antimicrobial and antioxidants due to the reduction in TVB-N values.

There is increasing public health concern regarding high sodium intake. The World Health Organization (WHO) recently reviewed the guideline for sodium intake $(\mathrm{WHO}, 2012)$ and confirmed their earlier conclusions regarding the adverse effects of high sodium intakes on blood pressure, and consequently on the risk of cardiovascular disease throughout the world.

Nowadays, International health authorities recommend salt reduction content in food products to improve the public health (WHO,2012; Dotsch -Klerk et al., 2015; Kurtz et al.,2018; Mork et al.,2019; Pedro and Nunes,2019). Sodium chloride is the main sodium source added for food preparation and processes.

Many people on sodium restricted or health-oriented diet avoid smoked fish consumption because of its high sodium content. As shown in Table (4) the salt content in fresh muscle fish (control sample) was $0.18 \mathrm{~g} / 100 \mathrm{~g}$ and increased after liquid smoking treatments to $1.79,1.66,1.77$ and $1.74 \mathrm{~g} / 100 \mathrm{~g}$ in LS, LS+p1, LS+P2 and LS+P1+P samples respectively. This increase in salt content values might be due to salting and drying during smoking (Cardinal et al., 2001; Alcicek,2011). Results revealed a slight increase in salt content to be 1.98 after 65 days in LS, 1.84 after 70 days in LS+P1, 1.83 after 70 days in $\mathrm{LS}+\mathrm{P} 2$ and 1.81 after 75 days in $\mathrm{LS}+\mathrm{P} 1+\mathrm{P}$. This increase in salt content might be due to Partial dehydration (Martinez et al.,2011). According to WHO (2012) current salt intake recommends of $5 \mathrm{~g} / \mathrm{d}$. Interestingly, the detected salt content in all liquid smoked treatments were much lower than recommended limit. smoked fish with low salt content will encourage consumers, improve the public health and enhance safety.

Effect of liquid smoked on $\mathrm{pH}$ of mullet (Mugil cephalus) fish during storage at $4{ }^{\circ} \mathrm{C}$ is shown in Table (4). The initial $\mathrm{pH}$ value for fresh fish used in this study was 6.56. Significant decreases $(P<0.05)$ were obtained with all liquid smoked samples compared to fresh fish sample. This decrease may be due to the presence of acid in liquid smoke which deposited on the fish during liquid smoking process (Alcicek, 2011; Bouzgarrou et al.,2016). After 6 days of storage at $4{ }^{\circ} \mathrm{C}$ the $\mathrm{pH}$ values of samples treated with LS, LS+P1, LS+P2 and $\mathrm{LS}+\mathrm{P} 1+\mathrm{P} 2$ were significantly decreased $(\mathrm{P}<0.05)$ as compared with fresh fish. The $\mathrm{pH}$ value of fresh fish increased rapidly du to formation of volatile nitrogen amines resulting from microbial fish spoilage (Alcicek, 2011; Bouzgarrou et al.,2016).

Treatment of fish with $2 \%$ lactic acid buffered will exert antimicrobial, reduce $\mathrm{pH}$ and enhance safety and quality. The most marked result was noted in the treatment with $\mathrm{LS}+\mathrm{P} 1+\mathrm{P} 2$, which prolongs shelf life to 75 days at $4{ }^{\circ} \mathrm{C}$ and improve safety and quality, while ensuring low salt content was much lower than WHO recommended limit. Synergistic effect was observed between LS and $\mathrm{P} 1, \mathrm{LS}$ and $\mathrm{P} 2$, LS and $\mathrm{P} 1+\mathrm{P} 2$. In this study during storage period at $4{ }^{\circ} \mathrm{C}$ 


\section{REFERENCES}

Alcicek , Z. (2011). The effects of thyme (Thymus vulgaris L.) oil concentration on liquid-smoked vacuum-packed rainbow trout (Oncorhynchus mykiss Walbaum, 1792) fillets during chilled storage. Food chemistry, 128(3), 683-688.

Alcicek, Z. (2014). Effects of Different Liquid Smoke Flavor Levels on the Shelf Life of Venus Clam (Chamelea Gallina, L 1758) Meat. Journal of food processing and preservation, 38(3), 964-970.

Alcicek, Z., Zencir, O., Celik Cakırog ulları, G., \& Atar, H. H. (2010). The Effect of Liquid Smoking of Anchovy (Engraulis encrasicolus, L. 1758) Fillets on Sensory, Meat Yield, Polycyclic Aromatic Hydrocarbons (PAHs) Content and Chemical Changes and antimicrobial properties of fish gelatin films as active packaging. Food Hydrocolloids, 89: 253-259.

Al-Reza, S., Karmaker, S., Hasan, M., Roy, S., Hoque, R., \& Rahman, N. (2015).

Effect of traditional fish processing methods on the proximate and microbiological characteristics of Laubuka dadiburjori during storage. Journal of Fisheries and Aquatic Science, 10(4), 232.

Ao, K. D., Omolara, F. M. O., \& Eteobong, N. (2017). Comparative study on length weight relationship of the grey mullet Mugil cephalus (Linnaeus 1758) and sickle fin Liza falcipinnis (Valenciennes, 1836) from Lagos Lagoon,Nigeria.

AOAC (1984). Official methods of analysis (14th ed.). Washington, DC: Association of Official Analytical Chemists, USA.

Bouzgarrou, O., El Mzougui, N., \& Sadok, S. (2016). Smoking and polyphenols' addition to improve freshwater mullet (Mugil cephalus) fillets' quality attributes during refrigerated storage. International journal of food science \& technology, 51(1), 268-277.

Cardinal, M., Knockaert, C., Torrissen, O., Sigurgisladottir, S., Mørkøre, T., Thomassen, M., \& Vallet, J. L. (2001). Relation of smoking parameters to the yield, colour and sensory quality of smoked Atlantic salmon (Salmo salar). Food Research International, 34(6), 537-550.

Ceylan, Z., Sengor, G. F. U., \& Yilmaz, M. T. (2018). Nanoencapsulation of liquid smoke/thymol combination in chitosan nanofibers to delay microbiological spoilage of sea bass (Dicentrarchus labrax) fillets. Journal of food engineering, 229, 43-49.

Chaillou, S., Chaulot-Talmon, A., Caekebeke, H., Cardinal, M., Christieans, S., Denis, C., \& Champomier-Verges, C. (2015). Origin and ecological selection of core and food-specific bacterial communities associated with meat and seafood spoilage. The ISME J., 9:1105-1118.

Çoban,E. \& Kelestemur,T.G.(2016). Qualitative improvement of catfish burger using Zataria multiflora Boiss. essential oil. J. Food Measure. \& Characteri., 34:1-8

Dimitriadou, D., Zotos, A., Petridis, D., \& Taylor, A. K. D. (2008). Improvement in the production of smoked trout fillets (Salmo gairdnerii) steamed with liquid smoke. Food Science and Technology International, 14(1), 67-77.

Diop, M., Watier, D., Masson, P. Y., Diouf, A., Amara, R., Grard, T., \& Lencel, P. (2016). Assessment of freshness and freeze-thawing of sea 
bream fillets (Sparus aurata) by a cytosolic enzyme: Lactate dehydrogenase. Food chemistry, 210, 428-434.

Dotsch -Klerk, M., Goossens, W. P., Meijer, G. W., \& van Het Hof, K. H. (2015). Reducing salt in food; setting product-specific criteria aiming at a salt intake of $5 \mathrm{~g}$ per day. European journal of clinical nutrition, 69(7), 799.

Fan, W., Chi, Y., \& Zhang, S. (2008). The use of a tea polyphenol dip to extend the shelf life of silver carp (Hypophthalmicthys molitrix) during storage in ice. Food chemistry, 108(1), 148-153.

Ghaly, A. E., Dave, D., Budge, S., \& Brooks, M. S. (2010). Fish spoilage mechanisms and preservation techniques. American Journal of Applied Sciences, 7(7), 859.

Goulas, A. E., \& Kontominas, M. G. (2005). Effect of salting and smokingmethod on the keeping quality of chub mackerel (Scomber japonicus): biochemical and sensory attributes. Food chemistry, 93(3), 511-520.

Guan, W., Ren, X., Li, Y., \& Mao, L. (2019). The beneficial effects of grape seed, sage and oregano extracts on the quality and volatile flavor component of hairtail fish balls during cold storage at $4^{\circ} \mathrm{C}$ LWT, $101,25-$ 31.

Hanania,Z., Yee,F. \& Nor-Khaizura ,M.(2019). Effect of pomegranate (Punica granatum L.) peel powder on the antioxidant antioxidant and antimicrobial properties of fish gelatin films as active packaging. Food Hydrocolloids, 89, 253-259.

Hassoun, A. \& Coban,O. (2017) Essential oils for antimicrobial and antioxidant applications in fish and other seafood products:Areview. Trends in Food Sci. \& Tech., 68: 26-36.

Iheagwara, C. (2013). Effect of ginger extract on stability and sensorial quality of smoked mackerel (Scomber scombrus) fish. Nutrition \& Food Sciences., 3:3-13

Jnr, M. H., Kinigoma, B. S., \& Spiff, A. I. (2006). Evaluation of the levels of total volatile bases and trimethyleamine formed in fish stored at low temperature. Bulletin of the Chemical Society of Ethiopia, 20(1), 155-159.

Karoui, R., \& Hassoun, A. (2017). Efficiency of rosemary and basil essential oils on the shelf-life extension of atlantic mackerel (Scomber Scombrus) fillets stored at 2 C. J. AOAC, 100: 335-344.

Kharchoufi, S., Licciardello, F., Siracusa, L., Muratore, Kolsarici,N., \& Ozkaya,O. (1998). Effect of smoking methods on shelf-life of rainbow trout (Salmo gairdneri). Turkish Journal of Veterinary and Animal Sciences, 22(3), 273-284.

Kurtz, T. W., DiCarlo, S. E., Pravenec, M., \& Morris, R. C. (2018). Functional foods for augmenting nitric oxide activity and reducing the risk for saltinduced hypertension and cardiovascular disease in Japan. Journal of cardiology, 72(1), 42-49.

Lazo, O., Guerrero, L., Alexi, N., Grigorakis, K., Claret, A., Pérez, J. A., \& Bou, R. (2017). Sensory characterization, physico-chemical properties and somatic yields of five emerging fish species. Food Research International, 100, 396-406.

Ledesma, E., Rendueles, M., \& Díaz, M. (2017). Smoked Food. In Current Developments in Biotechnology and Bioengineering (pp. 201-243). Elsevier. 
Lingbeck, J. M., Cordero, P., O'Bryan, C. A., Johnson, M. G., Ricke, S. C., \& Crandall, P. G. (2014). Functionality of liquid smoke as an all-natural antimicrobial in food preservation. Meat Science, 97(2), 197-206.

Mahugija, J. A. M., \& Njale, E. (2018). Levels of polycyclic aromatic hydrocarbons (PAHs) in smoked and sun-dried fish samples from areas in Lake Victoria in Mwanza, Tanzania. Journal of Food Composition and Analysis, 73:39-46.

Martinez, O., Salmerón, J., \& Guillén, M. D. (2011). Characteristics of dry-and brine-salted salmon later treated with liquid smoke flavouring. Agricultural and food science, 20(3), 217-227.

Mendonca A. , Davis,A. , Moutiq,R. , \& Thomas,E.(2018). Chapter 14 - Use of Natural Antimicrobials of Plant Origin to Improve the Micobiological Safety of Foods. In Food \& Feed Safety Syst. \&Anal. 249-272.

Metin, S., Erkan, N., Varlik, C., \& Aran, N. (2001). Extension of shelf-life of chub mackerel (Scomber japonicus Houttuyn 1780) treated with lactic acid. European Food Research and Technology, 213(3), 174-177.

Miller, D. D. (1998). Lipid peroxidation. Food chemistry: A laboratory manual. New York, NY, USA: Wiley-Interscience, John Wiley \& Sons, 57-67.

Mork , T., Lahteenmaki , L., \& Grunert, K. G. (2019). Determinants of intention to reduce salt intake and willingness to purchase salt-reduced food products: Evidence from a web survey. Appetite, 139, 110-118.

Mostafa, A.A. \& Salem, R.H. (2015). Characterization of microbiological and nutritional variations in processed mullet (Mugil cephalus) Fish. International Journal of Microbiological Research, 6, 108-122.

Noori, S. M. A., Khanzadi, S., Fazlara, A., Najafzadehvarzi, H., \& Azizzadeh, M. (2018). Effect of lactic acid and ajwain (Carum copticum) on the biogenic amines and quality of refrigerated common carp (Cyprinus carpio). LWT, 97, 434-439.

Olafsdottir, G., Martinsdóttir, E., Oehlenschläger, J., Dalgaard, P., Jensen, B., Undeland, I., \& Nilsen, H. (1997). Methods to evaluate fish freshness in research and industry. Trends in Food Science \& Technology, 8(8), 258-265.

Orak, H. H., \& Kayisoglu, S. (2008). Quality changes in whole, gutted and filleted three fish species (Gadus euxinus, Mugil cephalus, Engraulis encrasicholus) at frozen storage period (-26 C). Acta Scientiarum Polonorum Technologia Alimentaria, 7(3), 15-28.

Ozogul, Y., \& Ozogul, F. (2004). Effects of slaughtering methods on sensory, chemical and microbiological quality of rainbow trout (Onchorynchus mykiss) stored in ice and MAP. European Food Research and Technology, 219(3), 211-216.

Pearson, D. (1973). Flesh foods, meat and fish in laboratory techniques in food analysis, pp. 166-212.

Pedro, S., \& Nunes, M. L. (2019). Reducing salt levels in seafood products. In Reducing Salt in Foods (pp. 185-211). Woodhead Publishing.

Pezeshk, S., Rezaei, M., \& Hosseini, H. (2011). Effects of turmeric, shallot extracts, and their combination on quality characteristics of vacuumpackaged rainbow trout stored at $4 \pm 1^{\circ} \mathrm{C}$. Journal of food science, 76(6), M387-M391. 
Pisoschi,A., Pop,A., Georgescu,C., Turcus,V., Olah,N. \&Mathe,E.(2018). An overview of natural antimicrobials role in food.: Review. European Journal of Medicinal Chemistry, $143:$ 922-935.

Rascon, A. J., Azzouz, A., \& Ballesteros, E. (2019). Trace level determination of polycyclic aromatic hydrocarbons in raw and processed meat and fish products from European markets by GC-MS. Food Control, 101, 198$208 .$.

Ribeiro, J. S., Santos, M. J. M. C., Silva, L. K. R., Pereira, L. C. L., Santos, I. A., da Silva Lannes, S. C., \& Silva, M. V. (2019). Natural antioxidants used in meat products: A brief review. Meat science 148:181-188.

Sampels, S. (2015). The effects of storage and preservation technologies on the quality of fish products: a review. Journal of food processing and preservation, 39(6), 1206-1215.

Secci, G., \& Parisi, G. (2016). Lipid oxidation in fish products. A review. Italy. J. Animal Sci., 15:124-136

Shirazinejad, A., Ismail, N., \& Bhat, R. (2010). Lactic acid as a potential decontaminant of selected foodborne pathogenic bacteria in shrimp (Penaeus merguiensis de Man). Foodborne pathogens and disease, 7(12), 1531-1536.

Siskos, I., Zotos, A., \& Taylor, K. A. (2005). The effect of drying, pressure and processing time on the quality of liquid-smoked trout (Salmo gairdnerii) fillets. Journal of the Science of Food and Agriculture, 85(12), 2054-2060.

Sun, X., Guo,X.,Ji,M.,Wu.,J. \& Zhang,Q.(2019). Preservative effects of fish gelatin coating enriched with CUR/ $\beta C D$ emulsion on grass carp (Ctenopharyngodon idellus) fillets during storage at $4{ }^{\circ} \mathrm{C}$. Food chem.,272:643-653.

A., Arcella, D., Carere, A., Croera, C., Engel, K. H., Gott, D. \& Simon, R. (2012). Safety assessment of smoke flavouring primary products by the European Food Safety Authority. Trends in food science \& technology, 27(2), 97-108.

Varlet, V.,Serot,T. \& Prost,C.(2009). Smoke flavoring technology in seafood. In Handbook of seafood and seafood products analysis (pp. 251-272). CRC Press.

Waltham, N. J., Teasdale, P. R., \& Connolly, R. M. (2013). Use of flathead mullet (Mugil cephalus) in coastal biomonitor studies: Review and recommendations for future studies. Marine pollution bulletin, 69(1-2), 195-205.

Wang, G. Y., Huang, X. Z., Zhu, J. L., \& Fu, Y. Y. (2014). Effect of ozone water, electrolyzed water and high salt solution on the quality of large yellow croaker during the refrigerated storage. Science and Technology of Food Industry, 35, 343-346.

Wang, W., Li, M., Fang, W., Pradhan, A. K., \& Li, Y. (2013). A predictive model for assessment of decontamination effects of lactic acid and chitosan used in combination on Vibrio parahaemolyticus in shrimps. International journal of food microbiology, 167(2), 124-130.

Wells, N., Yusufu, D., \& Mills, A. (2019). Colorimetric plastic film indicator for the detection of the volatile basic nitrogen compounds associated with fish spoilage. Talanta, 194, 830-836.

World Health Organization. (2012). Guideline: Sodium intake for adults and children. World Health Organization. 
Zanin, L., Cunha, D., \& Rosso,V. (2017). Knowledge, attitudes and practices of food handlers in food safety: An integrative review. Food Res. Inte. 100: 53-62.

Zeitoun, A. A. M., Debevere, J. M., \& Mossel, D. A. A. (1994). Significance of Enterobacteriaceae as index organisms for hygiene on fresh untreated poultry, poultry treated with lactic acid and poultry stored in a modified atmosphere. Food Microbiology, 11(2), 169-176.

$$
\text { الملخص العربي }
$$

\title{
مضادات الأكسدة ومضادات الميكرويات الطبيعية وعلاقتها بجودة وسلامة المبة أسماك البوري المدخنة
}

\author{
'روان أشرف عبدالمنعم زيتون و' أحمد السيد عبد الله و طارق محمد أحمد سرور \\ "محمد أبو طالب السبد حساتين \\ ا.قسم علوم الأغذية - كلية الزراعة -سابا باشنا- الإسكندرية \\ r.قسم الانتاج الحيواني والسمكي - كلية الزراعة سابا باشاء - الإسكندرية \\ r.المعهد القومي لعلوم البحار و المصايد
}

تم اجراء معاملات مختلفه باستخدام سائل التنخين علي سمك البوري الطازج (Mugi cephalus) يث

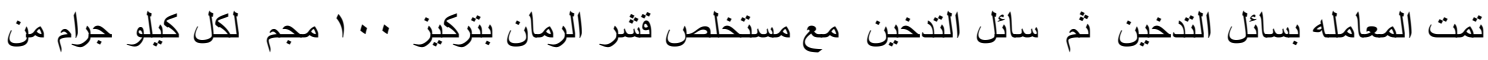

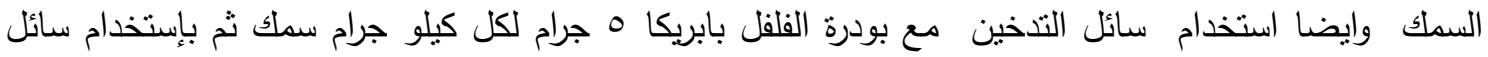

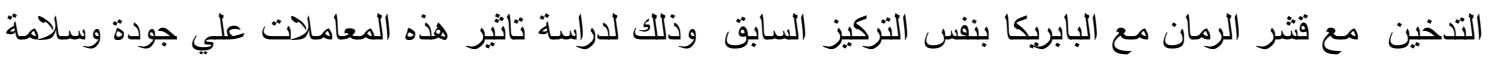

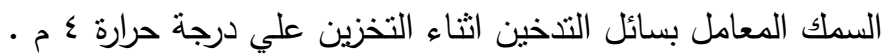

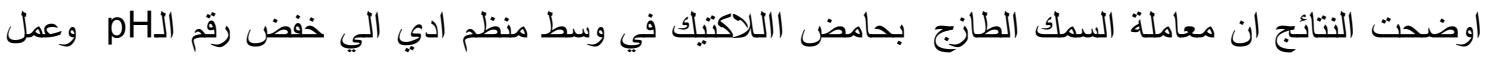
كمضاد للميكروبات ودعم الجوده والسلامه . .

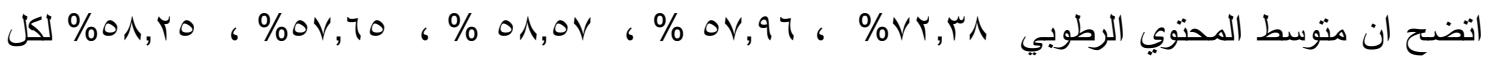

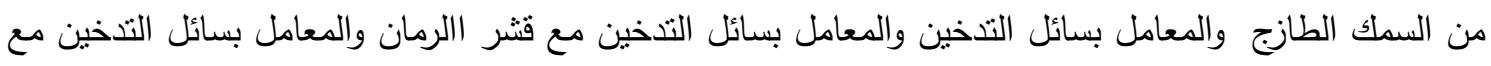
البابريكا واخيرا والمعامل بسائل التنخين مع قشر الرمان والبابريكا علي التوالي . اظهرت كل معاملات بسائل التذخين انخفاض معنوي في المحتوي الرطوبي للعينات المعامله من السمك مقارنه

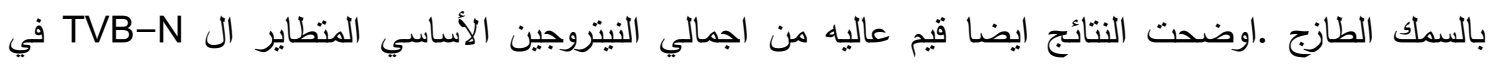

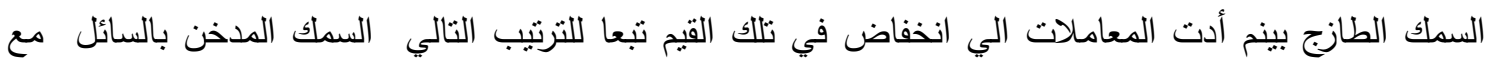

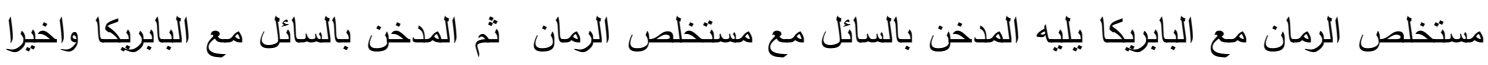

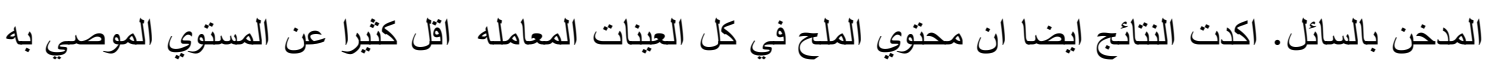
من قبل WHO حيث يؤدي المستوي المنخفض من الملح الي تشجيع الاستهلاك ويدعم سلامة المنتج ويحسن

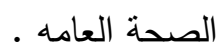


اكدت النتائج ايضا ان العينات المعامله بسائل التدخين والمعامله بسائل التدخين مع مستخلص الرمان و المعامله

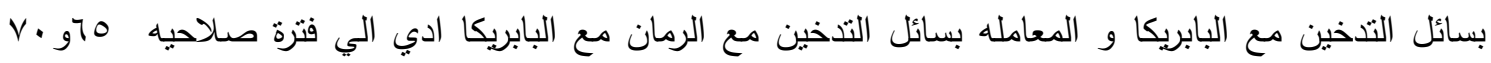

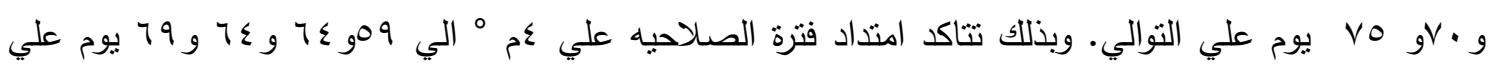
التوالي عند المقارنه بالسمك الغير معامل . 
